\title{
ANALISIS WACANA KELAS DALAM PEMBELAJARAN BAHASA INDONESIA PADA PELAKSANAAN DEBAT KELAS X SMA NEGERI 09 KOTA BENGKULU TAHUN AJARAN 2019
}

\author{
'Tri Rizki Meri Handayani; ${ }^{2}$ Agus Trianto; ${ }^{3}$ Ria Ariesta
}

\section{Program Studi Pendidikan Bahasa Indonesia Jurusan Bahasa dan Seni FKIP Universitas Bengkulu}

Abstrak

\section{Korespondensi: tririzkimerihandayani94574@gmail.com}

Tujuan penelitian ini adalah untuk mendeskripsikan analisis wacana kelas dalam pembelajaran Bahasa Indonesia pada pelaksanaan debat kelas X SMA Negeri 09 Kota Bengkulu. Metode penelitian yang digunakan adalah metode deskriptif kualitatif. Data pada penelitian ini menggunakan catatan lapangan observasi. Sumber data pada penelitian ini yaitu guru dan siswa pada pelaksanaan debat. Teknik pengumpulan data yang digunakan adalah teknik observasi. Teknik analisis data dalam penelitian ini: (1) pentranskripsian data, (3) pengkodean data, (4) pengklasifikasian data, (5) penyimpulan data. Hasil penelitian ini dalam wacana kelas terdapat empat pola dalam peristiwa tutur pembelajaran yaitu Teacher Structuring terdapat delapan peristiwa diantaranya: tindak menyatakan, rasa syukur, ungkapan pujian, ungkapan kepuasan, tindak berusaha, tindak mendikte, penanaman kebiasaan tertib dan penumbuhan ketertiban menyusun pertanyaan. Teacher Soliciting terdapat tiga puluh satu peristiwa diantaranya: tindak memberitahukan, memperkirakan, menegaskan, menyimpulkan, meyakini, rasa eling, ungkapan pemberian maaf, menjanjikan, mengajak, menjamin, memerintah, membatasi, menuntun, mensyaratkan, meminta, mengajak, mengundang, menasihati, mengingatkan, membolehkan, mengizinkan, menoleransi, kebiasaan sopan, menyusun jawaban, menyatakan pendapat, memberikan komentar, bekerja sama secara berpasangan, bekerja sama secara klasikal dan rasa yakin. Learner Responding terdapat peristiwa tindak menolak dan Teacher Reacting terdapat dua belas peristiwa diantaranya: tindak menyetujui, mengakui, ungkapan kekhawatiran, ungkapan kekecewaan, permintaan maaf, mengancam, menginstruksi, memperingatkan, bertanya, menyarankan, kebiasaan disiplin, dan rasa berani.

Kata Kunci: wacana kelas, pelaksanaan debat

\section{Abstract}

The research was conducted to describe the class discourse in Indonesian Language learning in the implementation of state high school class X debate 09 Bengkulu City. This research was method a descriptive qualitative method. The data in this research used the observation field record. Sources of data in this study are teachers and students during the debate. Data collection techniques used are observation techniques. tools of this research Data analysis techniques in this study: (1) transcribing data, (3) coding data, (4) classification of data, (5) data inference. The results of this study in class discourse there are four patterns in the learning speech event, namely Teacher Structuring, there are eight events including: acts of 


\section{Tri Rizki Meri Handayani; Agus Trianto; Ria Ariesta}

expressiveness, gratitude, expressions of praise, expressions of satisfaction, action, dictation, cultivation of orderly habits and growth in order to arrange questions. Teacher Soliciting has thirty-one events including: the act of notifying, estimating, affirming, concluding, believing, feeling eling, expressing the apology, promising, inviting, guaranteeing, governing, limiting, guiding, requiring, asking, inviting, inviting, advising, reminding , allowing, permitting, tolerating, polite habits, compiling answers, expressing opinions, giving comments, collaborating in a general manner, cooperating in a classical manner and feeling confident. Responding Learner is a refusal event and Teacher Reacting there are twelve events including: the act of approving, acknowledging, expressing worries, expressing disappointment, apologizing, threatening, instructing, warning, asking questions, suggesting, disciplinary habits, and feeling brave.

Keywords: Class discourse, debating

\section{PENDAHULUAN}

Sekolah sebagai wadah pendidikan formal dan tempat menuntut ilmu, di mana dalam sekolah tersebut terdapat adanya guru, siswa, sarana dan prasarana. Dengan adanya itu, maka proses dalam belajar mengajar akan terlaksana dengan lancar. Pembelajaran di dalam kelas melibatkan antara guru dan siswa, guru sebagai fasilitator mengajarkan materi dalam kelas dan siswa dapat menerima dengan baik materi yang diajarkan guru. Berbagai macam masalah di dalam kelas terutama saat proses pembelajaran berlangsung. Terkadang saat guru menjelaskan materi siswa banyak yang ribut, mengobrol dengan temannya ataupun mengganggu teman yang sedang belajar.

Wacana kelas berkaitan dengan interaksi guru dan siswa. Bukan hanya bahasa guru dalam mengajar atau menjelaskan materi saja, bahasa guru dalam memberi nasihat ataupun teguran kepada siswanya juga terdapat dalam wacana kelas. Wacana kelas berisi tentang kegiatan yang secara langsung terjadi di dalam kelas. Dari awal pembelajaran dimulai sampai akhir pembelajaran selesai. Pada proses pembelajaran tentu banyak tindakan yang dilakukan oleh guru dan siswa seperti, tindak menyatakan, memberitahu, menegaskan, memperkirakan, menyimpulkan, meyakini, menyetujui, mengakui dan menolak. Dalam tindakan tersebut pada wacana kelas disebut dengan penalaran. Bukan hanya penalaran saja dalam wacana kelas terdapat juga aspek rasa. Aspek rasa menurut Dewantara (1977) dalam (Suwingnyo, 66: 2012) merupakan potensi jiwa yang bersifat biologis. Eksistensinya bersifat permanen, kewajiban guru menebaltipiskan potensi rasa yang ada. Rasa negatif ditipiskan dan rasa yang positif ditebalkan. Sikap kemauan (karsa) juga terdapat dalam wacana kelas, sikap karsa tersebut di antaranya terdapat karsa mau dan karsa mantap.

Pada wacana kelas terdapat empat pola dalam pembelajaran, yaitu pola tindakan penyiapan situasi/ kondisi (teacher structuring) dilakukan pada awal pembelajaran di mana siswa dapat berkonsentrasi pada topik atau materi yang akan dibahas nantinya. Tindakan mengundang tanggapan siswa (teacher soliciting), dilakukan pada saat proses pembelajaran guru dapat bertanya kepada siswa, siswa dapat mengemukakan pendapatnya terhadap pembelajaran yang dilakukan. Tindakan menanggapi oleh siswa (learner responding), tindakan ini menyuruh siswa untuk merespons, misalnya merespons pertanyaan yang diajukan oleh guru. Tindakan mereaksi atas hasil tanggapan siswa (teacher reacting), 
dilakukan oleh guru untuk mereaksi kualitas respons siswa berupa penguatan ataupun pengoreksian.

Maka dari itu, rumusan masalah penelitian yaitu Bagaimana wacana kelas dalam pembelajaran Bahasa Indonesia pada pelaksanaan debat SMA Negeri 09 Kota Bengkulu? Sejalan dengan rumusan masalah di atas, maka tujuan penelitian ini untuk mendeskripsikan wacana kelas dalam pembelajaran Bahasa Indonesia pada pelaksanaan debat SMA Negeri 09 Kota Bengkulu. Sinclair dan Coulthard memberikan definisi tindakan wacana. Wacana tindakan biasanya satu klausa bebas, ditambah klausa bawahan, tetapi ada yang pasti kelas tertutup di mana kita dapat menentukan hampir semua kemungkinan realisasi yang terdiri atas kata atau grup tunggal. Suatu tindakan harus selalu dimulai dengan unit nada baru. Ini diketahui bahwa jeda akan memberi paling awal dan akhir dari suatu tindakan. Model Analisis Wacana (DA), juga dikenal sebagai model Birmingham atau, pada tingkat pertukaran, struktur Initiation Response-Follow-up (IRF), dikembangkan oleh Sinclair dan Coulthard dari penelitian mengenai deskripsi struktural wacana ditemukan di ruang kelas. Sejak deskripsi aslinya pada tahun 1975, ia telah berevolusi dan diperluas untuk memungkinkan penerapan wacana yang kurang terstruktur.

Struktur wacana kelas didasarkan pada pandangan bahwa suatu peristiwa tutur berisi satu kegiatan atau aspek kegiatan yang secara langsung diatur oleh norma penggunaan tutur Hymes, 1971 (dalam, Suwignyo, 2012: 27). Peristiwa tutur terjadi dalam satu situasi tutur yang terdiri atas satu tindak tutur atau lebih. Jika suatu transaksi isi pembelajaran merupakan situasi tutur, maka rangkaian tindakan pembelajaran merupakan peristiwa tutur dengan muatan satu atau lebih tindak tutur pembelajaran. Oleh karena itu mendasar tindakan structuring, soliciting, responding, dan reacting sebagai peristiwa tutur berarti menjadikan keempat peristiwa tutur tersebut ke unit analisis tindak tutur pembelajaran. Analisis wacana kelas menggunakan teori Bellack 1973 (dalam, Suwignyo, 2012: 27) menegaskan terdapat empat pola tindakan dalam peristiwa pembelajaran, yakni pola tindakan penyiapan situasi atau kondisi pembelajaran disebut peristiwa teacher structuring, tindakan mengundang tanggapan siswa disebut peristiwa teacher soliciting, tindakan menanggapi oleh siswa atau peristiwa learner responding, dan tindakan mereaksi atas hasil tanggapan siswa disebut peristiwa teacher reacting.

Pola tindakan penyiapan situasi kondisi (Teacher Structuring) terdiri atas: tindak menyatakan, rasa syukur, ungkapan pujian, ungkapan kepuasan, tindak berusaha, tindak membatasi, tindak mendikte, penanaman kebiasaan tertib. Tindakan mengundang tanggapan siswa (Teacher Soliciting) peristiwa soliciting di antaranya: tindak memberitahukan, tindak memperkirakan, tindak menegaskan, tindak menyimpulkan, tindak meyakini, rasa eling, ungkapan pemberian maaf, tindak menjanjikan, tindak mengajak, tindak menawarkan, tindak menjamin, tindak memerintah, tindak membatasi, tindak menuntun, tindak mensyaratkan, tindak mengundang, tindak menasihati, tindak mengingatkan, tindak membolehkan, tindak mengizinkan, tindak menoleransi, penanaman kebiasaan bertanggung jawab, penanaman kebiasaan jujur, penanaman kebiasaan sopan, penumbuhan keterlibatan menyusun jawaban, menumbuhkan keterlibatan menyatakan pendapat, penumbuhan keterlibatan menyatakan keinginan/kehendak, penumbuhan keterlibatan memberikan komentar, bekerja sama secara berpasangan, bekerja sama secara klasikal, dan rasa yakin. 


\section{Tri Rizki Meri Handayani; Agus Trianto; Ria Ariesta}

Tindakan menanggapi oleh siswa (Learner responding) terdapat peristiwa tindak menolak. Tindakan mereaksi (teacher reacting) peristiwa reacting seperti: tindak menyetujui, tindak mengakui, ungkapan kekhawatiran, ungkapan kekecewaan, permintaan maaf, tindak mengancam, tindak menginstruksi, tindak memperingatkan, tindak bertanya, tindak menyarankan, penanaman kebiasaan disiplin, dan rasa berani. Suherli dkk. (2006: 175) mengemukakan debat adalah dua pihak saling bertukar pendapat dengan mengemukakan berbagai alasan, meskipun keduanya berada pada sudut pandang yang berbeda. Debat adalah kegiatan untuk mempertahankan pendapat dengan disertai argumen yang mendukung pendapat. Debat juga dapat diartikan kegiatan adu argumentasi antara dua pihak atau lebih itu perorangan ataupun kelompok dalam mendiskusikan dan memutuskan masalah dan perbedaan.

Bagian-bagian dalam debat diantaranya:

a. Mosi adalah hal atau topik yang diperdebatkan.

b. Tim afirmatif, yakni tim yang setuju terdapat hal yang diperdebatkan (mosi).

c. Tim negatif atau oposisi, yakni tim yang tidak setuju atau menantang mosi.

d. Tim netral, yakni orang yang memberikan 2 sisi baik dukungan ataupun sanggahan terhadap mosi.

e. Moderator, yakni orang yang memimpin dan membantu jalannya perdebatan.

f. Penulis, yakni orang yang menulis kesimpulan suatu debat.

Menurut Paul, 1993: 4 (dalam Fisher, 2009: 4) Berpikir kritis adalah mode berpikir mengenal hal, substansi atau masalah apa saja dimana si pemikir meningkatkan kualitas pemikirannya dengan menangani secara terampil struktur-struktur yang melekat dalam pemikiran dan menerapkan standar-standar intelektual padanya. McPeck, 1981 (dalam Kuswana, 2011: 21) mendefinisikan berpikir kritis sebagai ketepatan penggunaan skeptis reflektif dari suatu masalah, yang dipertimbangkan sebagai suatu permasalahan.

\section{METODE}

Metode penelitian yang digunakan dalam penelitian ini adalah metode deskriptif kualitatif. Metode deskriptif dengan pendekatan kualitatif digunakan sesuai dengan tujuan yang ingin dicapai untuk mendapatkan analisis wacana kelas pada pelaksanaan debat siswa kelas X IPS 2 SMA Negeri 09 Kota Bengkulu. Penelitian ini menggunakan pendekatan kualitatif karena data yang diambil adalah data yang benar-benar terjadi pada saat itu dan tidak dibuat-buat. Penelitian ini dilaksanakan Sekolah Menengah Atas (SMA) Negeri 09 Kota Bengkulu, Subjek yang diteliti pada penelitian ini yaitu pada siswa kelas X IPS 2. Waktu penelitian ini dilaksanakan pada tanggal 15 April - 3 Mei 2019. Instrumen dalam penelitian ini adalah pedoman observasi Data adalah bukti sekaligus isyarat (Bogdan \& Biklen, 2007: 117 dalam Emzir, 2010: 65).

Data pada penelitian ini catatan lapangan observasi. Sumber data pada penelitian ini yaitu guru dan siswa dalam pembelajaran Bahasa Indonesia pada pelaksanaan debat. Langkah-langkah analisis data: pentranskripsian data, data yang berupa bahasa lisan guru dalam proses pembelajaran yang diperoleh dari rekaman, kemudian ditranskripsikan dalam bentuk tulisan atau dalam bentuk wacana dialog. Pengkodean data, setelah data ditranskripsikan, kemudian diberi kode di setiap ujaran di setiap ujaran baik ujaran dari guru maupun siswa, pengkodean dilakukan dengan cara memberi nomor, agar mudah dalam menganalisisnya. Pengklasifikasian data, data yang sudah ditranskripsikan dan di beri kode, selanjutnya dilakukan pengklasifikasian dari setiap ujaran yang ada untuk 
dikelompokkan. Setelah data di klasifikasi (dikelompokkan) kemudian dianalisis, langkah terakhir adalah melakukan penyimpulan dari analisis yang telah dilakukan. Validitas yang digunakan pada penelitian ini triangulasi sumber dan triangulasi teknik.

\section{HASIL DAN PEMBAHASAN}

\section{Hasil}

A. Pola Tindakan Penyiapan Situasi Kondisi (Teacher Structuring)

Peristiwa structuring adalah keterarahan dan pemfokusan konsentrasi siswa pada topik pembelajaran yang diberikan guru.

- Tindak Menyatakan

Tindak menyatakan dilakukan guru saat pembelajaran Bahasa Indonesia saat membahas topik debat yang akan diajarkan kepada siswa.

71. G : Materi sering didengar tapi jarang dilakukan untuk kegiatan formal, kegiatan tidak formal sering dilakukan ya, apalagi kita baru sudah melaksanakan kegiatan pemilihan Presiden dan Wakil-wakil rakyat ya, Pemilu 17 April 2019 kemarin, yang kegiatan apa namanya, sebelum kegiatan pemilu itu ada beberapa pemilih yang dilakukan oleh para pemimpin dan calon pemimpin di televisi. Mudah-mudahan nonton.

Guru menjelaskan topik yang akan dibahas, sebelum membahas topik tersebut guru menyatakan bahwa materi yang akan ia ajarkan merupakan materi yang sering didengar, sering juga dilakukan tetapi pada forum-forum yang tidak resmi sedangkan pada forum resmi hal tersebut jarang dilakukan.

B. Tindakan Mengundang Tanggapan Siswa (Teacher Soliciting)

Peristiwa soliciting adalah peristiwa yang berguna untuk menggerakkan siswa, mengundang tanggapan siswa selama proses pembelajaran berlangsung.

- Tindak Memberitahukan

Tindak memberitahukan adalah sesuatu yang disampaikan dalam bentuk ilmu pengetahuan, tindak memberitahukan dituturkan guru untuk menyampaikan informasi konseptual.

98. G : Jadi dalam debat itu ada kelompok pro, ada kelompok kontra, ada kelompok netral ya, seperti kita ketahui kalimat pro dan kontra suka juga didengar ya, eee pro dan kontra. Kalau pro yang menyetujui ambo pro nian kek kau, ambo kau aku padamu pokoknyo, pro berarti dia senang dengan kelompok menyetujui. Paham ini ya?

Guru memberitahukan kepada siswa tentang materi pembelajaran, serta menjelaskan materi yang akan ia jelaskan. Mengenai materi debat pada bagian pro atau yang menyetujui serta guru mencontohkan agar siswa mengetahui pembelajaran tersebut. Pada tulisan yang bercetak tebal di atas merupakan tindak memberitahukan yang disampaikan oleh guru.

C. Tindakan Menanggapi Oleh Siswa (Learner Responding)

Learner responding yaitu merespons, menanggapi pertanyaan, perintah dan tugas latihan yang diberikan oleh guru. Peristiwa merespons dapat berupa menjawab pertanyaan, menanggapi pertanyaan guru baik pengetahuan ataupun yang lainnya. Pada tindak merespons ini terdapat peristiwa tindak menolak.

- Tindak Menolak

Tindak menolak merupakan salah satu tanggapan respons yang dilakukan siswa terhadap pertanyaan maupun tugas yang dituturkan guru, dalam peristiwa ini 


\section{Tri Rizki Meri Handayani; Agus Trianto; Ria Ariesta}

tindak menolak yang dilakukan siswa saat pelaksanaan debat berlangsung. Tindak menolak di sini saat siswa menolak mosi dalam debat, atau siswa menentang mosi pada pelaksanaan debat.

455. K : Saya tidak setuju, tidak harus dengan kuliah kita akan mendapatkan pekerjaan, dengan tidak kuliah pun kita masih dapat pekerjaan malahan jika kita bekerja setelah SMA kita akan berpeluang mempunyai penghasilan sendiri tanpa membebani orang tua, kita dapat meringankan beban orang tua kalau kita bekerja tanpa harus kuliah. Dan, jika kita bekerja setelah SMA nantinya kita akan menjadi anak yang lebih mandiri lagi.

Kutipan yang bercetak tebal merupakan salah satu tindak menolak yang dituturkan siswa saat pelaksanaan debat. Tindak menolak ini dituturkan oleh tim kontra atau tim yang tidak menyetujui terhadap mosi.

D. Tindakan Mereaksi (Teacher Reacting)

Peristiwa mereaksi merupakan adanya reaksi guru atau siswa dalam menanggapi pertanyaan, perintah yang diberikan.

Tindak Menyetujui merupakan suatu tindakan setuju terhadap apa yang telah diucapkan seseorang, menyetujui diletakkan pada posisi guru sebagai pendengar, bahwa guru telah menerima pesan komunikasi dari siswa. Guru setuju dengan tanggapan siswa ataupun jawaban siswa "okeoke, ya".

69. G : Ya, kegiatan itu kegiatan debat

91. $G$ : Benar ya, yang pertama tadi benar juga tetapi pendapat yang kedua ini dikunci dengan alasan yang logis Alasan yang logis itu maksudnya apa nak? Tindak menyetujui ini dilakukan guru sebagai pendengar, dimana ia mendengar jawaban siswa kemudian menyetujui jawaban siswa sesuai dengan pengetahuan yang ia miliki. Tindak menyetujui misalnya "iya, oke, betul, benar dan lain sebagainya".

E. Argumentasi

Argumentasi merupakan salah satu jenis pengembangan paragraf dalam penulisan yang dituliskan dengan tujuan meyakinkan pendengar atau pembaca, tujuannya agar pembaca yakin tentang ide, gagasan atau pendapat yang telah disampaikannya.

P : Kalau menurut saya, saya sangat setuju dengan tema kali ini, yaitu pentingkah kuliah setelah SMA. Pertama, kuliah merupakan salah satu jenjang sekolah tinggi. Kedua, kuliah juga memberikan kesempatan kepada seluruh siswa untuk menentukan pilihan pekerjaannya ke depan, ataukah dalam perkuliahan nanti siswa dapat memilih bidang studi apa yang akan mereka ambil. Ketiga, ketika seseorang menentukan pilihannya untuk kuliah maka ia tidak berada pada ambang yang tidak menentu lagi karena ia sudah memasuki fase dewasa, jadi ketika siswa memilih pilihan untuk tetap kuliah seorang siswa itu sudah bisa dikatakan dewasa karena ia lebih mementingkan pendidikan dibanding kehidupan yang belum jelas arahnya. Itulah pendapat saya, saya setuju.

Kutipan di atas merupakan pendapat yang disampaikan dari kelompok pro atau tim yang menyetujui. Tim pro sangat menyetujui setelah lulus SMA dilanjutkan dengan kuliah karena dapat memilih pekerjaan sesuai dengan jurusan kita. Kutipan di atas merupakan argumen atau pendapat siswa saat pelaksanaan debat.

F. Sanggahan

Sanggahan merupakan kalimat yang tidak menyetujui tentang topik pembelajaran, atau terhadap suatu masalah atau pembicaraan. 
K: Saya tidak setuju, tidak harus dengan kuliah kita akan mendapatkan pekerjaan, dengan tidak kuliah pun kita masih dapat pekerjaan malahan jika kita bekerja setelah SMA kita akan berpeluang mempunyai penghasilan sendiri tanpa membebani orang tua, kita dapat meringankan beban orang tua kalau kita bekerja tanpa harus kuliah, jika kita bekerja setelah SMA nantinya kita akan menjadi anak yang lebih mandiri lagi.

Kutipan di atas merupakan salah satu sanggahan yang dituturkan tiap kelompok debat, dalam sanggahan ada beberapa hal yaitu ada pengungkapan ketidaksetujuan atau menolak, ada juga memberi tanggapan tandingan berupa fakta atau penemuan.

G. Pertanyaan dan Jawaban

Pertanyaan merupakan keingintahuan seseorang akan sebuah informasi yang dituangkan dalam kalimat tanya. Jawaban merupakan sahutan terhadap pertanyaan yang diajukan sehingga terbuka rasa ingin tahu. Dalam pelaksanaan setiap tim tentunya ada yang bertanya dengan tim lainnya. Gunanya agar dapat memperkuat pendapat yang telah disampaikan.

$\mathrm{K}$ : Kita lihat sekarang banyak sarjana-sarjana yang menganggur. Apakah dengan kita mendapatkan gelar sarjana kita akan menjadi sukses?

P : Baiklah saya akan menjawab pertanyaan dari tim kontra dari kalangan sarjana saja masih banyak yang menganggur apalagi kita yang hanya tamatan SMA, jelas saja lapangan pekerjaan yang kita dapatkan juga terbatas dan persyaratan yang kita miliki pun juga minim. Apakah dengan kita tidak berkuliah kita bisa mendapatkan pekerjaan yang kita inginkan, atau yang layak. Maka, dengan berkuliah kita bisa menjadi orang yang sukses karena bisa menambah wawasan kita, kita bisa bertambah penghasilan, kita bisa mendapatkan pekerjaan yang kita inginkan dan membuat bangga orang tua kita dan kita akan mengganti jeri payah orang tua kita setelah kita mendapatkan gelar S-1 atau pekerjaan yang kita inginkan. Itulah pendapat saya.

Kutipan di atas merupakan pertanyaan beserta jawaban dalam melaksanakan debat. Pertanyaan yang diajukan gunanya agar dapat memecahkan rasa ingin tahu tiap tim terhadap sesuatu yang ia ingin ketahui terhadap tim lawan

\section{Pembahasan}

Berdasarkan hasil observasi wacana kelas, pada kegiatan pembelajaran Bahasa Indonesia di kelas X IPS 2 SMA Negeri 09 Kota Bengkulu dengan menggunakan analisis wacana kelas menurut Bellack (1973) dalam Suwignyo, 2012:27 yang terdiri dari empat pola tindakan dalam peristiwa tutur pembelajaran, yaitu teacher structuring, teacher soliciting, learner responding, dan teacher reacting. Bellack 1973 (dalam, Suwignyo, 2012: 27) pada teacher structuring memiliki 8 tindakan pada teacher structuring memiliki 8 diantaranya: tindak menyatakan, rasa syukur, ungkapan pujian, ungkapan kepuasan, tindak berusaha, tindak mendikte, penanaman kebiasaan tertib, menyusun pertanyaan, tetapi data yang didapatkan saat penelitian hanya 7 tindakan yang tidak ditemukan pada ungkapan pujian. Delapan aspek tindakan peristiwa tutur dalam wacana kelas tersebut tindakan menyusun pertanyaan yang sering dilakukan guru dari pertemuan pertama sampai keempat guru melakukan menyusun pertanyaan gunanya untuk melatih siswa menjadi lebih aktif lagi dalam pembelajaran. Yang tidak muncul pada teacher structuring atau pola penyiapan situasi kondisi pada aspek ungkapan pujian. Karena saat proses penelitian penulis tidak 


\section{Tri Rizki Meri Handayani; Agus Trianto; Ria Ariesta}

menemukan data tersebut.

Pada tindakan menyatakan, kepuasan dan tindak berusaha muncul pada pertemuan pertama, kedua dan ketiga. Pada tindakan tindak mendikte dan penanaman kebiasaan tertib muncul pada dua pertemuan yaitu pertemuan pertama dan kedua. Rasa syukur dalam wacana kelas muncul pada pertemuan kedua dan ketiga. Teori Bellack pada teacher soliciting terdapat 31 peristiwa, diantaranya : tindak memberitahukan, tindak memperkirakan, tindak menegaskan, tindak menyimpulkan, tindak meyakini, rasa eling, ungkapan permintaan maaf, tindak menjanjikan, tindak mengajak, tindak menawarkan, tindak menjamin, tindak memerintah, tindak membatasi, tindak menuntun, tindak mensyaratkan, tindak mengundang, tindak menasihati, tindak mengingatkan, tindak membolehkan, tindak mengizinkan, tindak menoleransi, kebiasaan bertanggung jawab, kebiasaan jujur, kebiasaan sopan, menyusun jawaban, menyatakan pendapat, keinginan/kehendak, memberi komentar, bekerja sama secara berpasangan, bekerja sama secara klasikal, rasa yakin, tetapi data yang didapatkan pada penelitian 28 peristiwa. Yang tidak terdapat pada tindak pemberian maaf, menoleransi dan memberi komentar.

Tiga puluh satu peristiwa tersebut yang sering muncul dari empat pertemuan, terdapat pada aspek rasa eling dan kebiasaan sopan. Kedua aspek peristiwa wacana kelas tersebut yang sering muncul pada empat kali pertemuan. Pada pertemuan pertama sampai ketiga aspek yang sering muncul terdapat pada peristiwa tindak memberitahu, memperkirakan, menegaskan, mengajak, memerintah, menyusun jawaban, menyatakan pendapat, bekerja sama secara berpasangan dan bekerja sama secara klasikal. Kesembilan aspek tersebut selalu muncul di setiap pertemuan pertama, kedua, dan ketiga. Pada pertemuan pertama dan kedua yang sering muncul dalam wacana kelas terdapat pada peristiwa tindak meyakini, menjanjikan, menjamin, menuntun, mengingatkan, mengizinkan. Keenam aspek tersebut sering muncul pada pertemuan pertama dan kedua. Aspek tindak menawarkan, membatasi, mensyaratkan, menasihati, kebiasaan bertanggung jawab, kebiasaan jujur dan rasa yakin hanya terdapat pada pertemuan pertama. Di mana ketujuh aspek tersebut hanya muncul pada pertemuan pertama saja.

Aspek tindak mengundang terdapat pada pertemuan pertama dan ketiga. Tindakan ini mengundang tanggapan siswa agar siswa dapat berpikir lebih aktif lagi dalam proses pembelajaran. Peristiwa keinginan atau kehendak terdapat pada pertemuan pertama, kedua dan keempat di mana pertemuan ketiga tidak terdapat tindakan keinginan/kehendak yang dilakukan guru maupun siswa. Tindak membolehkan hanya muncul pada pertemuan kedua di mana guru yang membolehkan siswa keluar untuk keperluan pensi. Pada tindakan menyimpulkan hanya terdapat pada pertemuan keempat di mana yang menyimpulkan di sini adalah siswa, yang disimpulkan oleh siswa yaitu simpulan pada saat pelaksanaan debat berlangsung. Pada learner responding dalam teori Bellack 1973 hanya terdapat satu tindakan yaitu tindak menolak dalam penelitian yang didapatkan juga satu tindakan pada pertemuan keempat. Teacher reacting menurut Bellack 1973 memiliki 12 tindakan Tindak menyetujui, tindak mengakui, ungkapan kekhawatiran, ungkapan kekecewaan, permintaan maaf, tindak mengancam, tindak menginstruksi, tindak memperingatkan, bertanya, tindak menyarankan, disiplin, dan rasa berani., tetapi pada penelitian yang didapatkan hanya 11 tindakan, yang tidak terdapat pada tindak menginstruksi.

Aspek yang sering muncul di setiap pertemuan dari pertemuan pertama sampai keempat yaitu permintaan maaf. Pada pertemuan pertama dan kedua yang sering muncul 
pada aspek menyetujui, permintaan maaf, mengancam, memperingatkan, dan bertanya. Pada aspek mengakui, ungkapan kekhawatiran, kebiasaan disiplin dan rasa berani muncul pada pertemuan pertama. Keempat aspek tersebut terdapat pada pertemuan pertama saja. Aspek kekecewaan dan menyarankan hanya muncul pada pertemuan kedua saja. Guru merasa kecewa tidak bisa menonton debat menggunakan infocus dikarenakan listrik mati. Tindakan menyarankan dilakukan guru saat menyarankan siswa untuk menonton debat di youtobe berdasarkan link yang tertera di buku pelajaran. Aspek yang tidak muncul dalam teacher reacting ini terdapat pada peristiwa tindak menginstruksi. Wacana kelas pada pelaksanaan debat juga terdapat argumentasi, sanggahan, pertanyaan dan jawaban. Argumentasi merupakan siswa menuturkan pendapat mereka secara berkelompok atau individu yang disampaikan berdasarkan pendapat mereka dengan proses berpikir.

Sanggahan merupakan ketidaksetujuan terhadap pendapat tim lawan, di mana ia memiliki pendapat mereka sendiri dengan menguatkan berupa fakta-fakta yang ada di sekitarnya. Pertanyaan dilakukan agar dapat memecahkan rasa ingin tahu terhadap apa yang belum diketahui, permasalahan yang belum diketahui akan dipecahkan dengan jawaban. Dalam proses pembelajaran siswa di dalam kelas tidak terlalu aktif dalam mengemukakan pendapatnya masing-masing, siswa tidak berbicara jika tidak ada instruksi dari guru seperti saat guru menanyakan pertanyaan tentang debat ada beberapa siswa yang menjawab dan saat ditanya materi yang kurang jelas siswa hanya diam saja. Maka materi debat inilah melatih siswa untuk mengungkapkan pendapatnya masing-masing. Siswa banyak bicara saat proses pelaksanaan debat saja, saat pelaksanaan debat telah selesai guru juga mengharapkan kepada siswa semoga pembelajaran debat ini nantinya dapat menjadi bekal mereka saat masuk ke perguruan tinggi. Tetapi di sini guru tidak ada memberi arahan kepada siswa bahwa di dalam berdebat tidak boleh berbicara menggunakan nada tinggi walaupun lawan bicara kita adalah tim lawan tetapi nada bicara juga harus di kondisikan.

Pada saat guru masih menjelaskan materi debat siswa lebih banyak mendengarkan guru. Ada segelintir siswa yang bertanya dan menjawab pertanyaan guru, tidak semua siswa aktif di dalam kelas. Ketidakaktifan siswa di dalam kelas merupakan kebiasaan yang sering dilakukan karena kebanyakan siswa kurang percaya diri untuk mengungkapkan pendapatnya begitu juga dalam bertanya siswa masih belum dapat berpikir kritis dalam proses pembelajaran. Kebanyakan siswa hanya menerima materi yang disampaikan guru saja. Pada proses pembelajaran yang lebih dominan berbicara kebanyakan gurunya. Karena di sini guru lebih banyak menyampaikan materi, memberitahukan kepada siswa tentang pengetahuan yang akan ia sampaikan, yang lebih aktif di sini guru bukan siswanya. Siswanya kebanyakan hanya mendengarkan materi yang di sampaikan guru. Guru bertanya kepada siswa merupakan salah satu cara agar siswa berlatih menjadi lebih aktif dalam proses pembelajaran, tetapi di sini hanya beberapa siswa saja yang dapat menjawab pertanyaan guru dan bertanya kepada guru. Selebihnya hanya menerima materi, mendengarkan penjelasan dari guru.

\section{PENUTUP}

Berdasarkan hasil penelitian dan pembahasan dapat disimpulkan bahwa wacana kelas pada pelaksanaan debat di kelas X IPS 2 SMA Negeri 09 Kota Bengkulu, ditemukan empat pola tindakan tuturan dalam wacana kelas yaitu teacher structuring, teacher soliciting, learner responding dan teacher reacting. Pada teacher structuring atau pola penyiapan situasi 


\section{Tri Rizki Meri Handayani; Agus Trianto; Ria Ariesta}

kondisi, yang sering muncul pada tindakan menyusun pertanyaan, yang tidak muncul pada ungkapan pujian. Teacher soliciting yang sering muncul pada tindak kebiasaan sopan, yang tidak muncul pada pemberian maaf, menoleransi dan memberikan komentar. Pada learner responding hanya satu tindakan yaitu tindak menolak hanya terdapat pada pertemuan keempat. Teacher reacting yang sering muncul pada permintaan maaf dan yang tidak muncul pada tindak menginstruksi.

\section{DAFTAR RUJUKAN}

Emzir. (2010). Metodologi Penelitian Kualitatif Analisis Data. Jakarta: PT Raja Grafindo Persada.

Fisher, A. (2009). Berpikir Kritis Sebuah Pengantar. Cambridge: Penerbit Erlangga.

Kuswana, W. S. (2011). Taksonomi Berpikir. bandung: PT Remaja Rosdakarya.

Suherli, dkk. (2016). Bahasa Indonesia. Jakarta: Kementerian Pendidikan dan Kebudayaan.

Suwignyo, H. (2012). Wacana Kelas.Bandung: PT Refika Aditama. 